\title{
Proliferating Myositis: An Inflammatory Lesion often Misdiagnosed as A Malignant Tumor
}

\author{
FARIBA BINESH ${ }^{1}$, MOHAMMAD SOBHANARDEKANI $^{2}$, SOMAYEH ZABIHI ${ }^{1}$, NASIM BEHNIAFARD $^{3}$ \\ ${ }^{1}$ Department of Pathology, Shahid Sadoughi University of Medical Sciences, Yazd, Iran \\ ${ }^{2}$ Department of Radiology, Shahid Sadoughi University of Medical Sciences, Yazd, Iran \\ ${ }^{3}$ Otorhinolaryngology Research Center, Shahid Sadoughi University of Medical Sciences, Yazd, Iran
}

\begin{abstract}
Proliferative myositis (PM) is a rare inflammatory disease. Most commonly, the lesion occurs in the extremities. Regarding its fast growth and bizarre shape of the cellular components this entity commonly misdiagnosed and the patients undergo improper therapeutic approaches. In other words, it is often misdiagnosed as sarcoma. The diagnosis can only be made by the microscopic examination, so biopsy is mandatory. Here the authors report a patient with PM who was initially misdiagnosed as pleomorphic sarcoma of the lower extremity and explain this rare entity.

Proliferative myositis should be taken into account if a fast growing, intramuscular mass occurs in the extremities.
\end{abstract}

Key words: Proliferative myositis, Sarcoma, Diagnosis, Pathology.

\section{INTRODUCTION}

Pseudosarcomatous lesions are dilemma for a medical teamwork including pathologist and a surgeon. PM is a rare peudosarcomatous entity with reactive nature and an uneventful outcome. It can be confused with sarcoma not only clinically but also morphologically [1]. Hence a correct diagnosis is needed to prevent unnecessary radical surgery and treatment. As a matter of fact, PM is the intramuscular doublet of proliferative fasciitis. Although Kern is credited with the inventive description of PM, Ackerman reported the first cases in his study of "extraosseous non-neoplastic localized bone and cartilage formation" [2]. Like proliferative fasciitis, it is a fast growing mass that infiltrates muscle tissue in a diffuse pattern and is defined by grotesque giant cells with close likeness to ganglion cells. The symptoms are non-specific, and the diagnosis always depends on the histological evaluation of tissue gained by biopsy or excision [2]. It arises mainly in adults between 40 and 70 years without sex preference [3]. Here we describe a case of PM in a 66-years old female who presented with a rapid-growing, painful, irregular swelling in her right leg which was initially misdiagnosed as malignant tumor of the leg.

\section{CASE REPORT}

A 66-year-old lady referred to a local private clinic with complaint of a fast growing mass in the lateral part of her right leg. The mass was painful. Her symptom had begun 6 months before. She denied any history of trauma.

Under the diagnosis of malignant lesion the patient had undergone surgical excision. The pathology report of the resected material was pleomorphic sarcoma. After that, chemotherapy was prescribed. However, she refused chemotherapy and was visited by another physician in our hospital. The microscopic slides were sent to the pathology ward by the second physician. All the pathology slides were subsequently reviewed at our institution in conjunction with the radiographic studies. An MRI of the leg at an outside facility showed an ill-defined abnormal signal lesion in muscular structures of right calf in posterolateral aspect without considerable mass effect. There was a heterogeneous enhancement of mentioned region after contrast injection (Figure 1 and Figure 2). Histopathological examination of tissue showed a poorly circumscribed lesion composed of fibroblast-like cells along with bizarre giant cells resembling ganglion cells that involved the epimysium, perimysium, and endomysium (Figure $3 \mathrm{~A}$ and B). Mitosis was present, but not atypical. Residual muscle tissue showed atrophy however cartilage and osteoid were not found. A final diagnosis of PM was made.

\section{DISCUSSION}

PM is a self-limiting, benign, reactive process that is probably preceded by some type 
of muscular injury resulting in a proliferation of myofibroblasts.

Owing to its fast growing nature, frequently it is misdignosed as a malignant neoplasm.

The lesion is first noted as a palpable, more or less discrete, solitary mass.
It rarely causes tenderness or pain. However, the chief complaint in our patient was severe pain. On physical examination stigmata of an inflammatory process are usually absent [4]. The duration between onset and excision is usually less than several weeks.

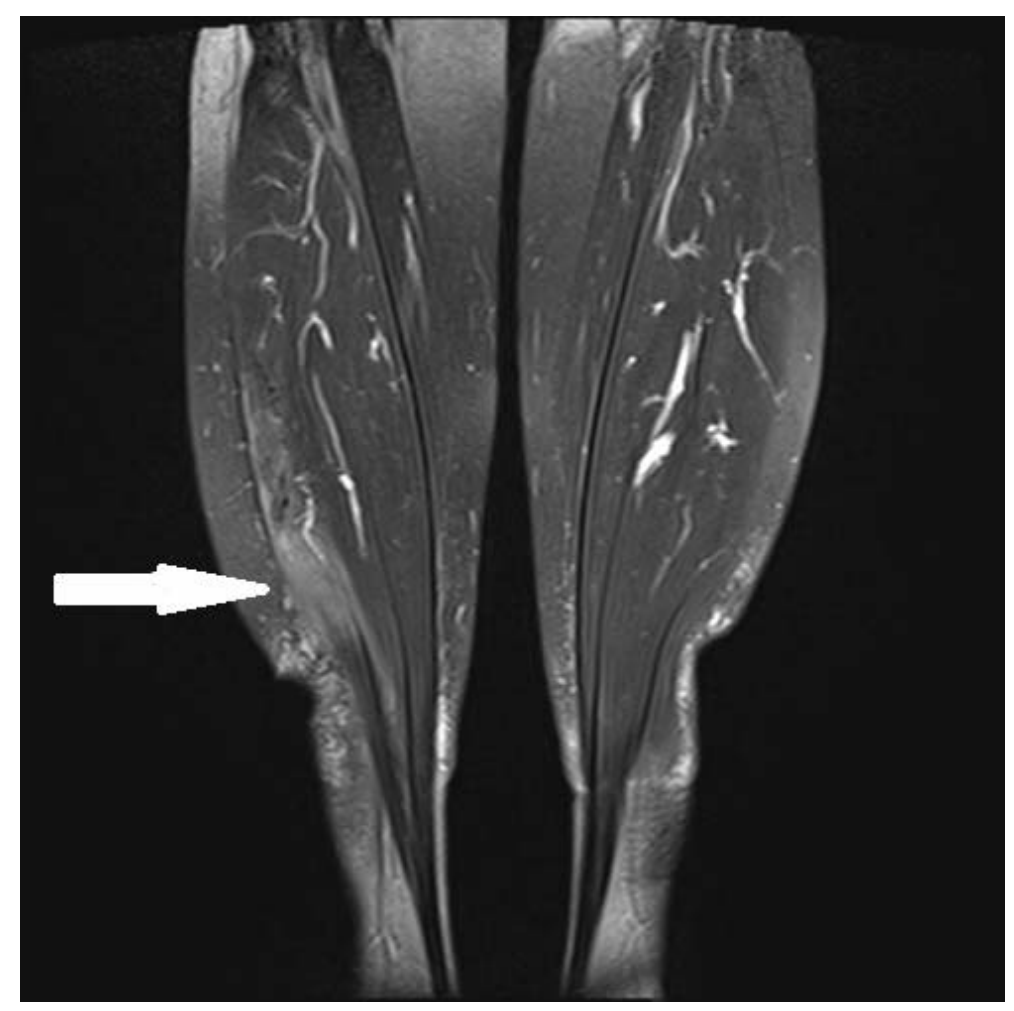

Figure 1. An ill-defined abnormal signal lesion in muscular structures of right calf in posterolateral aspect without considerable mass effect (Coronal view).

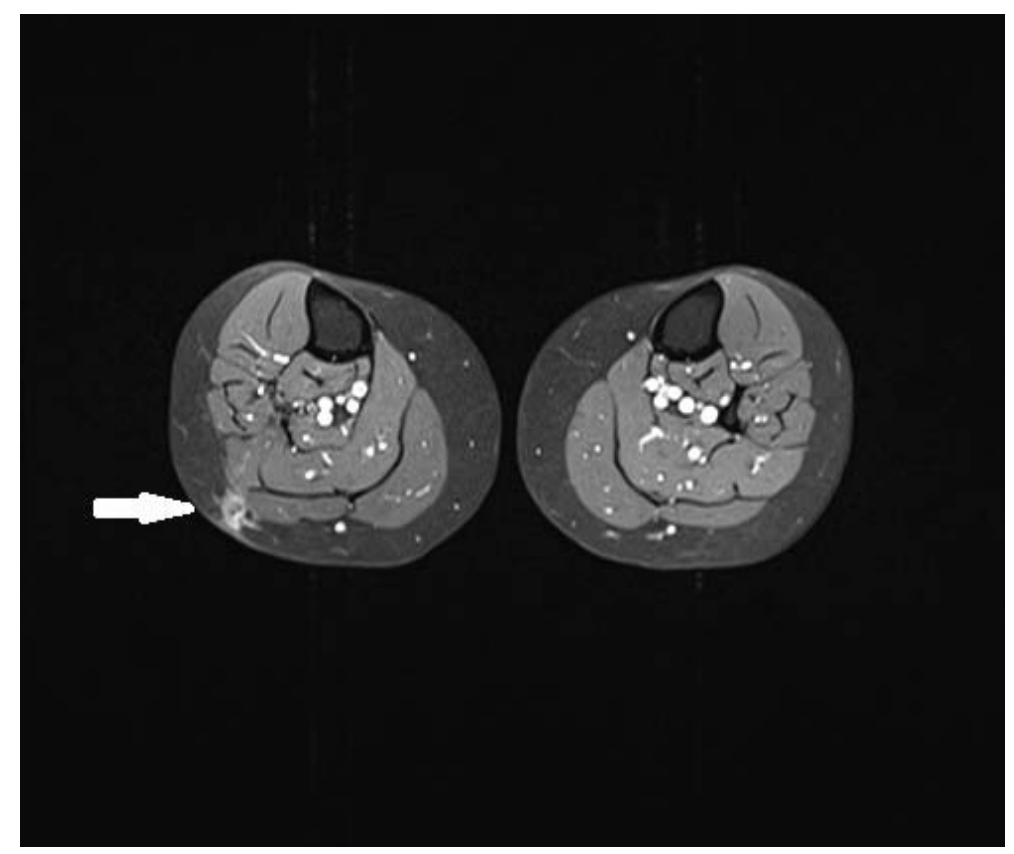

Figure 2. An ill-defined abnormal signal lesion in muscular structures of right calf in posterolateral aspect without considerable mass effect (Sagittal view). 


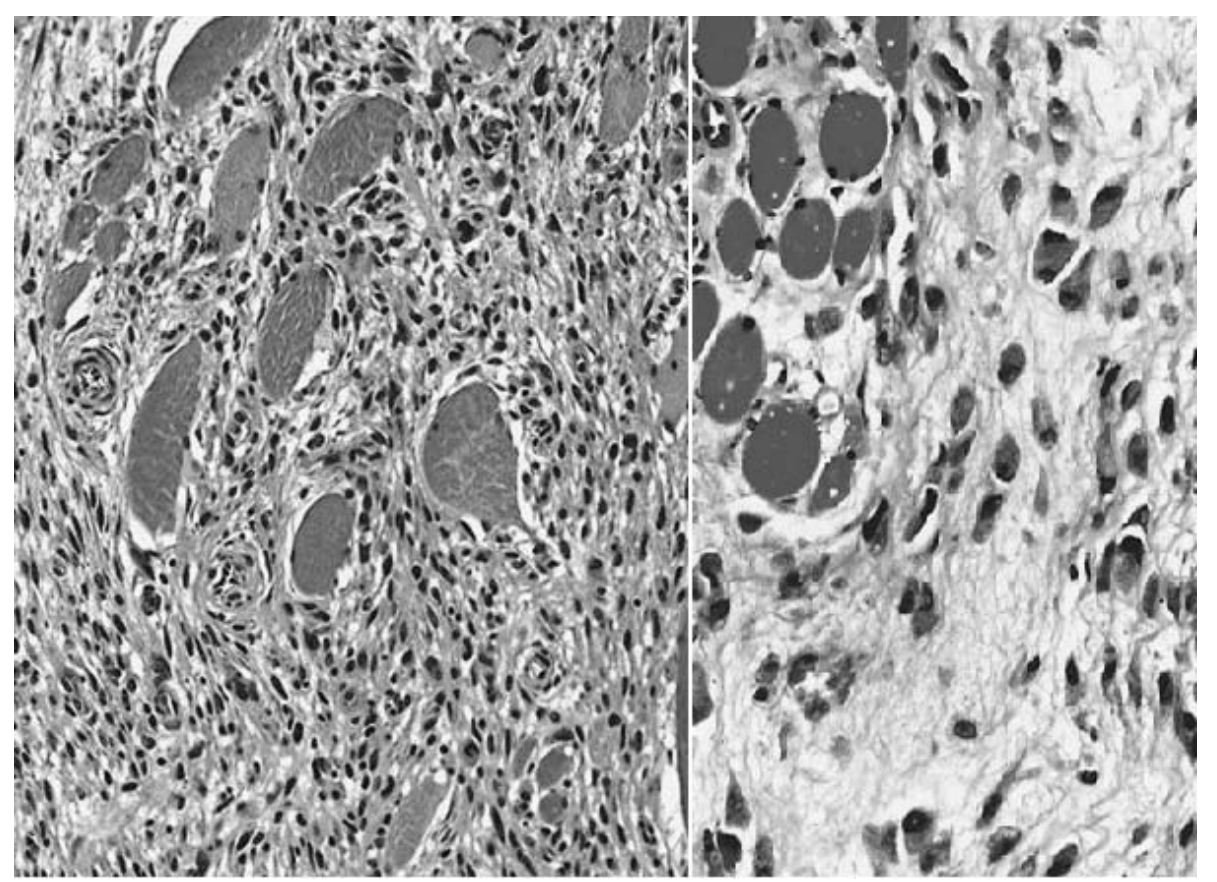

Figure 3. It reveals a poorly circumscribed lesion composed of fibroblast-like cells along with bizarre giant cells resembling ganglion cells that involved the muscle tissue (H \& E stain X 10 \& 40).

The patients tend to be older than those with nodular fasciitis, with a median age of 50 years. Our case was 66 years old. It seems to have no preference for either sex or any specific race. The lesion generally affects the muscles of the trunk and shoulder girdle. However, any muscle could be involved. For example, Joshua R. Colombo et al. presented a patient with PM involving sternohyoid muscle [4].

The exact etiology of this disease is obscure; however trauma has been suggested to be a predisposing agent.

In addition it is alluded that local ischemia, paracrine myopathy and chromosomal abnormalities have an important role [5]. Association of this disease with collagen vascular disease, desmoplastic fibroma and application of cast in cases with bone fracture has been noticed [6]. There is no characteristic CT feature in PM. As a result CT scan is not a method of choice in the diagnosis of this entity [7].

MRI enables high soft tissue resolution and can show diagnostic aspects for PM [8]. It is helpful for the surgeon by revealing the localization, size and bone condition. As clinical findings are non-specific, PM is usually diagnosed on histopathology. So microscopic evaluation is mandatory for proper diagnosis.

We should say that in one study, the authors reviewed 33 cases of PM and they showed that among these cases, 14 patients were misdiagnosed as precancerous or overt malignant tumors especially various sarcomas [9]. As a result of the wrong diagnoses, 11 patients had undergone unnecessary radical surgery.

Furthermore, MMA Jayawickrama reported 2 cases with PM who at first were misdiagnosed as sarcomas [10]. First patient was an old man who presented with a chest wall mass. The mentioned mass was painless. Initial diagnosis was spindle cell sarcoma. The other case was a young lady presented with a well circumscribed fast enlarging tender mass in her supraclavicular region. Again initial diagnosis was rhabdomyosarcoma. Revision of the slides related to both patients confirmed the diagnosis of PM. The differential diagnosis of PM includes myositis ossificans, other inflammatory myopathies and various sarcomas [11]. Proper diagnosis rests on patient's history and microscopic features.

Treatment modalities are different and include wait and watch or surgical intervention. To the best of our knowledge recurrence and malignant transformation have not been reported.

In conclusion, PM is a rare but benign lesion. Clinical and paraclinical features may be misleading. Its definite diagnosis is based on microscopic findings. Awareness of this disease will aid physicians to prevent improper treatment approaches.

Conflicts of interest. The authors confirm that there are no known conflicts of interest associated with this publication and there has been no significant financial support for this work that could have influenced its outcome. 
Miozita proliferativă (PM) este o boală rară inflamatorie. Cel mai frecvent leziunea apare la extremități. Datorită creşterii rapide şi a formelor bizare celulare această entitate este cel mai frecvent diagnosticată greşit şi pacienții sunt deseori tratați incorect. Diagnosticul cel mai frecvent cu care este confundat este sarcomul. Diagnosticul se face numai cu examenul histopatologic aşadar biopsia este obligatorie. In această prezentare autorii prezintă cazul unui pacient cu PM care a fost inițial diagnosticat eronat drept sarcom pleomorf al extremității inferioare.

$P M$ ar trebui luată în considerare atunci când o masă intramusculară creşte rapid la nivelul extremităților.

Correspondence to: Dr Fariba Binesh, M.D, Department of Pathology, Shahid Sadoughi Hospital,

Avicenna Blvd., Safayeh, Yazd, Iran, Tel.: +989131519609

E-mail: binesh44@yahoo.com

\section{REFERENCES}

1. ROSAI J. Soft tissues. In: Rosai and Ackerman's Surgical Pathology. Elsevier Health Sciences; 2011. 2114.

2. GOLDBLUM JR, WEISS SW, FOLPE AL. Benign fibroblastic/myofibroblastic proliferations. In: Enzinger and Weiss's soft tissue tumors, Elsevier Health Sciences; 2013. 192.

3. ZHANG J, BU XH, TIAN WZ, CHEN JH, WANG XL. Characteristic MR imaging findings of proliferative myositis. Acta Medica Mediterranea. 2014; 30(4):845-7.

4. COLOMBO JR, DAGHER W, WEIN RO. Benign proliferative myositis of the sternohyoid muscle: review and case report. Am J Otolaryngol. 2015; 36(1):87-9.

5. FAUSER C, NAHRIG J, NIEDERMEYER HP, ARNOLD W. Proliferative myositis: a rare pseudomalignant tumor of the head and neck. Arch Otolaryngol Head Neck Surg. 2008; 134(4):437-40.

6. YIGIT H, TURGUT AT, KOSAR P, ASTARCI HM, KOSAR U. Proliferative myositis presenting with a checkerboard-like pattern on CT. Diagn Interv Radiol. 2009; 15(2):139-42.

7. PAGONIDIS K, RAISSAKI M, GOURTSOYIANNIS N. Proliferative myositis: value of imaging. J Comput Assist Tomogr. 2005; 29(1):108-11.

8. JARRAYA M, PARVA P, STONE M, KLEIN MJ, GUERMAZI A. Atypical proliferative myositis: original MR description with pathologic correlation: case report. Skeletal Radiol. 2014; 43(8):1155-9.

9. ENZINGER FM, DULCEY F. Proliferative myositis. Report of thirty-three cases. Cancer. 1967; 20(12):2213-23.

10. JAYAWICKRAMA MM, JAYASEKARA HR, DE SILVA MV. Proliferating myositis and proliferating fasciitis: benign lesions often misdiagnosed as sarcomas. Ceylon Med J. 2005; 50(4):169-70.

11. 11. WLACHOVSKA B, ABRAHAM B, DEUX JF, SIBONY M, MARSAULT C, LE BRETON C. Proliferative myositis in a patient with AIDS, Skeletal Radiol. 2004 Apr; 33(4):237-40. Epub 2003 Dec 4.

Received May 30, 2016 